Warszawa 2019

PFLIT, issue 9(12), part 1: 163-174

CHRISTOPH AUGUSTYNOWICZ

Institute of East European History

University of Vienna

\title{
BETWEEN APPROPRIATION AND RIVALRY: SOME REMARKS ON THE CONCEPT OF EAST CENTRAL EUROPE IN RECENT ANGLO-AMERICAN AND GERMAN HISTORIOGRAPHY
}

Keywords: East Central Europe, Europe, historiography, memory, mental map

Słowa kluczowe: Europa Środkowo-Wschodnia, Europa, historiografia, pamięć, mapa mentalna

\section{S u m m a ry}

The present article follows some arguments that define East Central Europe on the fundament of a carefully selected choice of synthetically relevant literature, which shaped, profiled, and modified the discussion on the spatial-historical concept of East Central Europe in the last twenty-five years in English and German language. The article's structure has the following three sections:

- European Patterns and Differentiated Functions (Wandycz),

- Expanding Concepts and Decentralized Perspectives: The Turn of the Millennia (Longworth, Johnson, Bideleux/Jeffries, Niederhauser, Roth),

- Common Patterns and Linking Memory: Two Recent Examples (Puttkamer, Bahlcke/Rhodewald/Wünsch).

With the intention to correspond to the present volume's fundamental concept and main task, the article and its summary discuss whether there happened a shift from appropriation to rivalry in historiographical operationalization of the term "East Central Europe" in the last decades.

MIĘDZY ZAWŁASZCZENIEM A RYWALIZACJĄ:

KILKA UWAG NA TEMAT POJECIA EUROPY ŚRODKOWO-WSCHODNIEJ W NAJNOWSZEJ HISTORIOGRAFII ANGLO-AMERYKAŃSKIEJ I NIEMIECKIEJ

\section{Streszczenie}

Na podstawie wyboru relewantnej literatury w artykule przedstawiono założenia, które stały się podstawą definiowania Europy Środkowo-Wschodniej. Prześledzono w pracach opublikowanych w języku angielskim i niemieckim w ostatnich dwudziestu pięciu latach argumenty, które 
ukształtowały, sprofilowały i zmodyfikowały dyskusję na temat przestrzennej i historycznej koncepcji Europy Środkowo-Wschodniej. W strukturze artykułu wyodrębniono następujące trzy sekcje: (1) Europejskie wzorce i zróżnicowane funkcje pojęcia Europy Środkowo-Wschodniej (Wandycz);

(2) Rozszerzanie koncepcji Europy Środkowo-Wschodniej i zdecentralizowane perspektywy wypracowane po 1989 roku (Longworth, Johnson, Bideleux/Jeffries, Niederhauser, Roth); (3) Popularne modele Europy Środkowo-Wschodniej oraz jednoczące role pamięci (Puttkamer, Bahlcke/Rhodewald/Wünsch). Odnosząc się do pytań leżących u podstaw koncepcji tego numeru, Autor rozważa kwestie związane z przejściem od „przywłaszczenia” do „rywalizacji” w operowaniu terminem „Europa Środkowo-Wschodnia” w historiografii w ostatnich dziesięcioleciach.

When arguing in favor of operationalizing East Central Europe as a spatial concept for historiographic purposes, we must cope with two main subjects of the present publication. Like each historiographic construct, East Central Europe represents an appropriation, which simultaneously is also characterized by tendencies of rivalry, mainly in terms of inclusion and exclusion. This matter can be condensed to the questions: Who considers whom to be East Central European? How diverse populations coexist(ed) in and coinhabit(ed) comparably small areas? This article follows some arguments on defining East Central Europe based on a carefully selected choice of synthetically relevant literature, which shaped, profiled, and modified the discussion in the last twenty-five years in English and German language; therefore, represent examples of foreigners' perceptions and attributions. The choice is in no way complete as - except for section three - it mainly considers synthesizing works of concise (one-volume) scope.

When defining the use of the term of East Central Europe in this text, we must make two pragmatic distinctions. East Central Europe is distinguished from Eastern Europe, which mainly characterizes the part of Europe situated east of Germany and Italy in its respective historical formations. In that respect, Eastern Europe indicates the non-German and the non-Roman, hence mainly (but not exclusively) Slavic Europe. This text avoids the term Central Europe if possible due to its German-imperial connotation, which would focus on the German-speaking world and at least some of its eastern neighbors. Furthermore, some authors (including myself) distinguish East Central Europe from Southeastern Europe, which is contrasted to East Central Europe by geographical (mountains, sea) and climatic (mild seasonal transitions) features and a clearly evident historical reference to antiquity (ancient Greece, Rome).

The starting point for the discussion may be the perspective of Habsburg-Austrian officer's son and Polish historian Oskar Halecki. His definition of the notion dates back to the 1950s publications Borderlands of Western Civilization and The Limits and Divisions of European History, being considered as crucial 
for the historical definition of East Central Europe in recent surveys and overviews in print as well as on the internet. ${ }^{1}$ Halecki views the region and its history mainly as characterized by structural features like poly-ethnicity and corporative(-noble) liberty. When speaking of the medieval and early modern period, Halecki stresses the second serfdom and the governments of the Jagellonians and Habsburgs as main criteria, whereas during the nineteenth century he sees the region characterized by Austro-Hungarian (Habsburgs), Russian (Romanovs), and Prussian/German (Hohenzollern) government. In opposition to that kind of foreign domination, the regions and societies of East Central Europe developed nationalisms mostly linked to ethnicity and language. For the twentieth century, Halecki considers the region to be dominated mainly by the - indirect or direct - influence of fascisms and authoritarianisms, especially National Socialism and Communism.

This discussion about the inner structure of Europe - and the discussion about the definition of East Central Europe - received new impulses more than fifteen years after Halecki's death, with the opening of the Iron Curtain in 1989.

\section{European Patterns and Differentiated Functions: Piotr Wandycz}

Piotr Wandycz's The Price of Freedom: A History of East Central Europe from the Middle Ages to the Present (London: Routledge, 1992) can be considered paradigmatic for the concept of East Central Europe immediately after the transformation of 1989. Born in Poland, educated in France, the United Kingdom, and the USA, Wandycz published this synthesis in the immediate aftermath of 1989's events and changes. His main attempt was to introduce East Central Europe to USA readers, mostly uninformed about Europe in general and even less about its regional discourses. With focus on the contemporary - or at least twentieth century - references, Wandycz stresses that both World Wars and the Cold War began in East Central Europe. ${ }^{2}$ In terms of geopolitical connections and tensions, he unequivocally refers to the understanding of Europe between West and East and shapes his flexible definition of the region based on historically shifting political-administrative borders. Maybe it is Wandycz's Atlantic perspective that inspired his definition of the region exclusively on seas and, thereby, linked his approach to a vividly discussed

\footnotetext{
${ }^{1}$ https://ome-lexikon.uni-oldenburg.de/begriffe/ostmitteleuropa/, https://de.wikipedia.org/wiki/ Ostmitteleuropa (acc. 9.01.2019); also, vide Christoph Augustynowicz, Geschichte Ostmitteleuropas - Ein Abriss (Wien: new academic press, 2014), 24-32.

${ }^{2}$ Piotr Wandycz, The Price of Freedom. A History of East Central Europe from the Middle Ages to the Present (London: Routledge, 2001), 1.
} 
concept in Polish historiography. Accordingly, Wandycz's East Central Europe matches the territory between the Baltic Sea, the Adriatic Sea, the Aegean Sea, and the Black Sea.

Wandycz explicitly stresses that Europe's (rather mental) division into the west and the east is comparably new. During the eighteenth century, it superseded the continent's long term-dichotomy of the south and the north as characterizing the antagonism of the civilized Mediterranean south and the barbaric (continental) north. For example, the Enlightenment scholar August Ludwig Schlözer still in 1771 understood the history of Russia and East Central Europe explicitly as Northern History. Wandycz claims that in the period of Soviet Dominance during the second half of the twentieth century it were the political-pragmatic necessities that urged the opponents of Soviet-domination in East Central European societies to look to the east and reinvent and revitalize the claim of being situated in the center of Europe. To that end, they implemented the term Central Europe as intended to avoid imperial-aggressive tendencies, since the term Mitteleuropa had been used by the German politician and pastor Friedrich Naumann during the First World War to articulate the claims of German economic and political hegemony over its eastern neighbors. ${ }^{3}$

A paradigm of historical discussion added by Wandycz to the discussion about defining East Central Europe in an extension of Halecki's definition surfaces in the former's demarcation of centers and (semi-)peripheries according to the criteria introduced by world-system theorist Immanuel Wallerstein. Wandycz assigns those categories independently of the west-east paradigm, thus providing not only a further spatial differentiation of East Central Europe but also its integration into common European patterns. He stresses the necessity to differentiate with regards to functions in history. On the one hand, there is no doubt that East Central Europe can be evaluated as semi-periphery in terms of economic matters; on the other hand, however, the region provided impulses that can be charged as central from a perspective of cultural history. As examples, Wandycz indicates the Hussite movement in Bohemia in the early fifteenth century (which can be seen as proto-reformation more than a century before Luther) or the ideas of liberalism and constitutionalism in Poland and Hungary at the turn of the eighteenth and nineteenth centuries. He stresses the ignorance toward these impulses in western approach to be the main deficit in the perception of East Central Europe. Hence, the west and the east were, are, and remain more than spatial indicators. They are vectors in claims of progressiveness and demarcations against backwardness, they fundamentally contribute to drawing the collective mental map of Europe.

${ }^{3}$ Lonnie R. Johnson, Central Europe. Enemies, Neighbors, Friends (New York: Oxford University Press, 1996), 165ff. 
Wandycz stresses the following characteristics of his definition of East Central Europe: ${ }^{4}$

- Adaptation of Western cultural models during tenth-century Christianization that resulted in comparatively delayed cultural development within Europe.

- Insistence on agrarian structures; since the sixteenth century, Western regions simultaneously developed proto-industrial models (the exception of Bohemia).

- Discrepancy between socio-economic structures and institutional developments that resulted in a growing gap between the elites and the masses, lack of a middle class, and negative self-perception in regard to the deficit of modernization.

- Frictions during nation-building caused by persistence of ethnoreligious heterogeneity.

- Instability of borders until the twentieth century.

- Interruptions and discontinuities in terms of statehood.

- Affiliation to extensive, transregional, and transnational ${ }^{5}$ agglomerations of government, whose coherence was provided by dynasties (empires); symbolic struggle against foreign domination and the socio-economic distinctness of the peasant population.

- Presence of and interaction with German and Jewish population on a large scale, functional centers of Judaism.

- Concentrated and intensified transregional history, a "laboratory" ${ }^{6}$ for social systems.

Despite all discussions and differentiations, Wandycz permits no doubt about his own conceptual position. In continuation of Halecki's argumentation, Wandycz views Bohemia, Hungary, and Poland as members of the Western civilization by convincingly stating, that all of so-called Western Europe's major structural changes and impacts (the Renaissance, the Reformation, the Enlightenment, the French Revolution, and Industrial Revolution) influenced the regio; even more, they were co-developed by East Central Europe and its members.

\footnotetext{
${ }^{4}$ Piotr Wandycz, op. cit., 6-11.

${ }^{5}$ For more on transnationality as the fundamental element of the concept of East Central Europe, compare the most recent collection of articles Handbuch einer transnationalen Geschichte Ostmitteleuropas. Band I. Von der Mitte des 19. Jahrhunderts bis zum Ersten Weltkrieg, ed. Frank Hadler and Matthias Middell (Göttingen: Vandenhoeck \& Ruprecht, 2017).

${ }^{6}$ Piotr Wandycz, op. cit., 10.
} 


\section{Expanding Concepts and Decentralized Perspectives: The Turn of the Millenia}

The high importance of the idea of East Central Europe and the necessity to discuss Europe's historical and mental demarcations in the decade after 1989 is accompanied by a peak of historical syntheses in western languages released during that time, most of them in English. Several of them were even re-released after a rather short time. For example, Philip Longworth in his book The Making of Eastern Europe (London: Palgrave, 1992; several times modified and reprinted; in 1997 with the subtitle From Prehisory to Postcommunism) uses a chronologically regressive narrative, beginning in the present and telling history into the past. He traces the history of a generously defined Eastern Europe (including the Southeast) back to the transfer of the Roman Empire's capital from Rome to Constantinople in 324. Using a rather static concept, Longworth simplifies Eastern Europe as the "frontier dividing Charlemagne's Europe from the barbarian east." ${ }^{\prime 7}$ Lonnie R. Johnson's Central Europe. Enemies, Neighbors, Friends (Oxford: Oxford University Press 1996, 2011) presents an even more extensive understanding of Central Europe. Austria and Germany as, respectively, the Holy Roman Empire, the German Confederation, and the German Empire in the west and parts of Serbia and Bosnia-Hercegovina in the south are explicitly integrated in Johnson's notion of Central Europe. ${ }^{8} \mathrm{He}$ argues for a strong demarcation in the east by focusing on the idea of (East) Central Europe as the "Bulwark of Christendom." Besides that, Johnson follows the tried and tested concept of historically-politically shifting borders. Going back to the fourth century like Longworth, Johnson establishes a chronological-topical structure that follows common European criteria: the Middle Ages, the Reformation and Counterreformation, absolutism and the Enlightenment, the national period, the twentieth century as indicated by the World Wars.

At the turn of the millennia, there emerges a historiographical tendency to perceive as one spatial unit: East Central Europe and the more Mediterranean-mountainous and rather Ottoman region of Southeastern Europe; in many respects, an effort already done by Halecki. For instance, A History of Eastern Europe. Crisis and Change (London: Routledge, 1998, 2007) by Robert Bideleux and Ian Jeffries impresses readers by extensively elaborating in their introduction the concepts that spatially shape and structure Europe from a historical perspective. ${ }^{10}$ Subsequently, the authors treat East Central Europe and

\footnotetext{
${ }^{7}$ Philip Longworth, The Making of Eastern Europe (Basingstoke/London: Macmillan, 1992), 8.

${ }^{8}$ Lonnie R. Johnson, Central Europe. Enemies, Neighbors, Friends, V.

${ }^{9}$ Ibidem, 64ff.

${ }^{10}$ Robert Bideleux, Ian Jeffries, A History of Eastern Europe. Crisis and Change (London: Routledge, 1998), 8-34.
} 
Southeastern Europe as explicitly separate until the end of the nineteenth century. The political events are profoundly integrated into the social and economic background here. They trace Southeastern Europe back to the Greek-Roman period, whereas East Central Europe emerges with the seventh century; thus, the reference to antiquity becomes the main difference between the two regions. Concerning chronology, Bideleux and Jeffries replace the convention of periods by the key question: How East Central Europe's distance to the West changed? Again, the narrative follows the frames of governmental agglomerations (empires), that is Austria and the Habsburg Monarchy, Poland-Lithuania and the Polish territories. Much space is given to the year 1848 and, thereby, the issue of nation-building. Bideleux and Jeffries provide an integration of both regions (East Central Europe and Southeastern Europe) only in the twentieth century by a rather conventional division into the interwar period and the Second World War, the period of communism, and the time after the fall of the Iron Curtain.

A History of Eastern Europe since the Middle Ages by Emil Niederhauser (New York: Columbia University Press, 2003) disclaims such diversified spatial-chronological categories and integrates even the history of Russia. Hence, Niederhauser foregrounds the eighteenth century as the age of stabilization instead of decline - as the Polish-Lithuanian case would suggest - with the second half of the twentieth century exclusively viewed from the Soviet Union's perspective with regards to its figuration and expansion, its functioning and demise. Niederhauser operates on a wide scale of topics by considering economic factors along with political and social indicators; quite astonishing with his rather short bibliography. ${ }^{11}$ It seems, that the majority of the syntheses above ${ }^{12}$ devote many pages to the twentieth century, sometimes rather urgently and even artificially searching for parallels in the earlier epochs.

Studienhandbuch Östliches Europa edited by Harald Roth (Vol. 1; Stuttgart: UTB, 1999, 2009) follows a different approach than the examples presented so far, because it replaces the chronological structure with a topical and spatial approach. After considering the common characteristics of the region (historiography, borders, structure, political culture, society, religions, confessions, historical anthropology), Roth and his team design the historical regions of East Central Europe, Southeastern Europe, and - rather exceptionally - Northeastern Europe. Afterward, they attend to regions, states, and transregional ethnical and religious groups in detail. This work succeeds in decentralizing the perspective

${ }^{11}$ Emil Niederhauser, A History of Eastern Europe since the Middle Ages (Boulder: Social Science Monographs, 2003), 459ff.

${ }^{12}$ Vide Lonnie R. Johnson, Central Europe. Enemies, Neighbors, Friends; Robert Bideleux, Ian Jeffries, A History of Eastern Europe; Emil Niederhauser, A History of Eastern Europe. 
by taking into account not only (national) states but also telling the histories and showing the perspectives of smaller regions.

The works discussed so far represent the most recent overviews in that several of them were republished, some even revised and supplemented.

\section{Common Patterns and Linking Memory: Two Recent Examples}

Even more recent and strongly focused interests come from two results of German research. The first is Joachim von Puttkamer's Ostmitteleuropa im 19. und 20. Jahrhundert (East Central Europe in the 19th and 20th Century; Berlin: De Gruyter, 2010), who mainly attempts to countersign national historiographies' claims of particular East Central European for (national) exceptionalism or "exceptional path." Von Puttkamer stresses two common features of the East Central European region: the breaking of the corporative estate system by absolutism and the persistent social dominance of nobility. He claims that the latter developed into what a nobility corporate reform movement of the late eighteenth century that sought to link corporate-noble liberty with royal authority to establish constitutional statehood. According to Puttkamer, the noble elites's consensus in actively resisting absolutistic and mostly foreign oppression had a long-term effect in the idea of emancipating the dominant languages. In that respect, the 1848's revolutions were significant for the East Central European ethnicities in terms of a confrontation not only with the old absolutistic-restorative powers but also the new antagonist manifested in the idea of a united Germany. Convincingly offering alternative historical perspectives, Puttkamer stresses that the impact of German national-state unification on the Habsburg Monarchy opened completely new perspectives for Hungary, which would definitely have become hegemonic among the Monarchy's non-German ethnical groups. Anyhow, East Central European national states and societies emerged first of all within the frames of empires, and therefore by compromise. However, the idea of and struggle for freedom survived and became even more vivid in the fight against National Socialism and Communism in the twentieth century. Obviously, Puttkamer in many respects confirms Halecki's proposals.

Only after stressing these common characteristics does Puttkamer admit the East Central European regions' distinct historical developments. As already noticed by Wandycz, the Bohemian lands are a special case within the East Central European pattern, and Puttkamer's narrative includes that thought. The elites are not based on differentiation of nobility, but on the emancipation of bourgeoisie. Towns and industrialization are important factors of nineteenth-century dynamics, which have their continuities in a differentiated spectrum of political parties. Hence, Puttkamer emphasizes such characteristics 
as urbanization and the emergence of a working class or the development of modern social, administrative, and technical infrastructures, all of which approximate East Central Europe to the so-called common European patterns after the middle of the nineteenth century.

In terms of regional demarcations, Puttkamer defines soft borders for the hard core of East Central Europe (Bohemia/Czechoslovakia, Hungary, Poland) by acknowledging that it makes no sense to completely exclude Belarus, Western Ukraine, Croatia, Slovenia, Prussia, or Silesia - as well as the region's Jewish history. Thus, Puttkamer develops his narrative in two major branches, one dedicated to "description" and the other to "issues and topics under research." The description part rather conventionally follows chronological patterns: two chapters consider the nineteenth century, the interwar period, the Second World War and its consequences, socialism, and the transition period. Whereas the issues and topics under research are highly instructive. This section is framed by historiographical concepts of the region and the politics of history and cultures of remembrance. The further topical spectrum consists in the inequality of industrialization, corrosion of the nobility, and - confirming Puttkamer's introductory characterization - matters of ethnicity and nationality like ethnical diversity between isolation and symbiosis, nationalisms and national conflicts, imperial order and national statehood. The book concludes with an extensive multilingual - therefore enormously valuable - survey on recent research literature. ${ }^{13}$

The second example is the volume Religiöse Erinnerungsorte in Ostmitteleuropa. Konstitution und Konkurrenz im nationen- und epochenübergreifenden Zugriff (Religious Places of Memory in East Central Europe. Constitution and Competition in Transnational and Transepochal Approach; Berlin: Akademie Verlag, 2013) edited by Joachim Bahlcke, Stefan Rhodewald and Thomas Wünsch in cooperation with a large team of contributors. This encyclopedic work on religious manifestations of memory in terms of locations, artifacts, individuals, and events is strongly based on the idea of collective memory. Established by Maurice Halbwachs and further developed by Peter Burke and Jan Assmann, the concept considers remembrance as implicitly re-creative and, therefore, productive. In consequence, this volume traces remembrance and memory back to medieval times and emphasizes the fact that the characteristic of many saints and holy artifacts is the contrast of rather sparse secured data, on the one hand, and a vivid afterlife in terms of narrative dynamics on the other hand. For example, the battle for Częstochowa in 1655 is weakly documented, whereas the narrative of the miraculous Black Madonna, leading the Polish-Lithuanian forces to victory over the Swedes against all odds, is more vivid - and it was from the beginning.

\footnotetext{
${ }^{13}$ Joachim von Puttkamer, Ostmitteleuropa im 19. und 20. Jahrhundert (München: R. Oldenbourg, 2010), 251-326.
} 
It is not the essence of this event but the narrative of its aftermath, it is not its material concreteness but its symbolic function, which the editors consider to be significant and relevant for historiography. The editors' plea can be summarized as follows: Historians should not excavate the core of remembrance and memory but show its career and afterlife, its paramount and superior impact.

In the volume's preface, the early modern historian Thomas Wünsch emphasizes that phenomena like competition for and multiplicity of memory and remembrance were and are essential for Eastern Europe, as well as the processes of transfer and transgression in terms of chronology (from paganism to Christianity to communism/atheism) and in function (religious and political memory of constructing the nation), not to mention the phenomenon of multiple, overlapping, and fragmented memory. ${ }^{14}$ Another characteristic feature of East Central Europe that Wünsch foregrounds is the entangled coexistence of religious groups on small, sometimes even very small areas and territories, which evokes mechanisms like assimilation, cohabitation, or syncretism. Thus, collective memory has the potential to create identity and avoid - or at least regulate - conflict. The book covers recent sociological approaches, which understand and emphasize religion explicitly as a cohesive force.

Finally, Wünsch stresses religious cleavages to be extraordinarily significant in the East of Europe and subsequently pleads for historiographical concepts that counterbalance the national perspectives by showing transnational entities (historical regions, contact zones). Once again, the creation and narrative shaping of these medieval or early modern entities begins with the so-called national nineteenth century. Wünsch refers to Anderson's concept of the "imagined community" to highlight that they do have a future in terms of further self-definition in the present. Concrete examples, represented by lemmata in the volume's lexical part, are the church union of Brest, the seventeenth-century peace churches in Silesia, the Franciscan Brothers in Bosnia and Hercegovina, or the fortified churches (Kirchenburgen) in Transylvania.

\section{Summary}

How do definitions of East Central Europe discussed above cope with the conceptual terms of appropriation and rivalry and their functions in defining and shaping the region? All of the above authors more or less explicitly agree - the most unambiguous being Johnson and Puttkamer - that the borders of the East

${ }^{14}$ Thomas Wünsch, "Einleitung: Religiöse Erinnerungsorte in Ostmitteleuropa," in Religiöse Erinnerungsorte in Ostmitteleuropa. Konstitution und Konkurrenz im nationen- und epochenübergreifenden Zugriff, eds. Joachim Bahlcke, Stefan Rhodewald, Thomas Wünsch (Berlin: Akademie Verlag, 2013), XXV. 
Central European region are soft in terms of historically developed statehood. That is, we may define a core (the Bohemian, Hungarian, and Polish-Lithuanian lands) and an extended rim. Strikingly, Johnson and Puttkamer stress not only the entangled processes of the Southslavic ethnicities' nation-building but also the significance of the German unification in the nineteenth century. Roth solves that problem by decentralization, which his team realizes by primarily considering historical landscapes and regions; some of them certainly matching (national) states. Concerning the region's situation in Europe, the rhetorical figure of the land between (German) West and (Russian) East persists most explicitly in Wandycz, although it receives the most profound discussion and reflection in Bideleux and Jeffries.

Concerning the appropriation of characteristics from historical East Central Europe, there return two main arguments. That is, the dominant political position of nobility and a pronounced poly-ethnicity in terms of languages and religions. In many respects, the above authors confirm Halecki's fundamental criteria of definition. Soon after 1989, especially in Wandycz, a strong ambition for discussing and differentiating the region's suggested backwardness becomes evident. In terms of historiography, this tendency reflects the idea to integrate the picture of East Central Europe - as part of Europe - into concepts of trans-regional, even global divisions of functions and, especially, divided labor. Whereas, in terms of broader sociopolitical interests, this shows an optimism toward East Central Europe's integration into Europe and, furthermore, a discussion in global patterns.

A pronounced inclusive and argumentative moment in appropriating regions to become parts of East Central Europe becomes evident in the tendency of conceptually integrating the Southeast of Europe. This approach appears especially around the turn of the millennia, in Longworth, Johnson and Roth, and Bahlcke, Rhodewald, and Wünsch. The concept of the expansive integration of Europe, realized by the EU enlargements in 2004 and 2007, obviously occupied not only politicians but also historians. Not less obvious is the fact, that such generous inclusion of historical regions shapes a rather simplified Eastern Europe and implies a dangerous simplification, evident in the cases of Longworth or Niederhauser. A strong distinction in considering the various regions' different relations and connections to antiquity appears only in Bideleux and Jeffries. Roth and his team avoid that problem by mostly applying a spatial approach and discussing only subordinated chronology.

The historical discussion of inclusion in antique Europe certainly implies moments of rivalry as well: Who is more European? Who is actually and really European? Among the examined arguments there is a consensus about the question that the construct of East Central Europe implies strong moments of rivalry, especially in respect to processes of nation-building during the long 
nineteenth century as the time of transition from empire to (national) state. In the middle of the twentieth century, the models of poly-ethnical coexistence were replaced by the idea of homogenization, enforced by ideologies of excluding and polarizing mass mobilization, as Puttkamer puts it. By the way, Puttkamer himself stresses the potential significance of the German unification for the Hungarians in the frame of the Habsburg and Austro-Hungarian Monarchy. Undoubtedly, the most prominent and significant conceptual role plays rivalry for Bahlcke, Rhodewald, and Wünsch. The methodological potential of their approach becomes evident in cases of overlapping and even competing remembrance and memory and, subsequently, in deconstructions of exclusive claims on memory and demonstrating rather than including and bridging narratives of remembrance.

Is there a shift from appropriation (Wandycz, 1992) to rivalry (Wünsch, 2013) in historiographical operationalization of the term "East Central Europe" in the last decades? The answer "yes" would fit into the present volume's idea, but we must add that such shift is not linear but oscillating - and comparable to a heartbeat. Although this metaphor may be a little inept, it is suitable to show how much does the discussion on the region of East Central Europe remain vivid and fertile.

\section{References}

Augustynowicz, Christoph. Geschichte Ostmitteleuropas - Ein Abriss. Wien: nap (new academic press), 2014.

Bahlcke, Joachim, et Stefan Rhodewald, Wünsch Thomas, eds. Religiöse Erinnerungsorte in Ostmitteleuropa. Konstitution und Konkurrenz im nationen- und epochenübergreifenden Zugriff. Berlin: Akademie, 2013.

Bideleux, Robert, et Ian Jeffries, A History of Eastern Europe. Crisis and Change. London/New York: Routledge, 1998.

Johnson, Lonnie R. Central Europe. Enemies, Neighbors, Friends. New York/Oxford: Oxford University Press, 1996.

Longworth, Philip. The Making of Eastern Europe. Basingstoke/London: Macmillan, 1992.

Niederhauser, Emil. A History of Eastern Europe since the Middle Ages. Boulder/New York: Atlantic Research and Publications, 2003.

Puttkamer, Joachim von. Ostmitteleuropa im 19. und 20. Jahrhundert. München: Oldenbourg Verlag, 2010.

Roth, Harald, ed. Studienhandbuch Östliches Europa. Band 1 Wien/Köln/Weimar: Böhlau, 2009.

Wandycz, Piotr. The Price of Freedom. A History of East Central Europe from the Middle Ages to the Present. London/New York: Routledge, 2001. 